\title{
Influence of environmental parameters on the distribution of macrofauna in clam beds in tropical estuary
}

\section{N. SIVASHANKAR AND T. CH. JHANSI LAKSHMI BAI}

Article Chronicle :

Received:

19.10.2015;

Revised :

24.10.2015;

Accepted :

09.11.2015
ABSTRACT : The distribution of benthos in relation to environmental variables was studied in Mulki estuary, Dakshina Kannada, Karnataka. The study was carried out from August, 2007 to July, 2008 from the four different locations in the Mulki estuary. The hydrographical parameters had a significant effect on the distribution of clams between stations and months. Mollusca, polychaetes and crustaceans became the dominating groups in the benthic community and higher populations were observed during the premonsoon and post monsoon season. The mean population density of $M$. casta and P. malabarica varied from 43 to 83 and 29 to $60 \mathrm{no} . / \mathrm{m}^{2}$, respectively, with pre and postmonsoon recorded good numbers of spat population.

HOW TO CITE THIS ARTICLE : Sivashankar, N. and Bai, T. Ch. Jhansi Lakshmi (2015). Influence of environmental parameters on the distribution of macrofauna in clam beds in tropical estuary. Asian J. Environ. Sci.,10(2): 133-137.

Key Words :

Estuary,

Variables,

Macrobenthos,

Monsoon

Author for correspondence :

\section{N. SIVASHANKAR}

Department of Fisheries,

College of Agriculture

(U.A.S.)Bheemarayanagudi,

YADGIR (KARNATAKA)

INDIA

Email: sivareddyn@

rediffmail.com

See end of the article for

Coopted authors' 